\title{
The effect of iron substrate on mitochondrial haem synthesis in copper deficiency
}

\author{
BY DARRYL M. WILLIAMS, F. SCOTT KENNEDY \\ AND BRENDA G. GREEN \\ Departments of Internal Medicine and Biochemistry, Louisiana State University Medical \\ Center in Shreveport, PO Box 33932, Shreveport, Louisiana 71130-3932, USA
}

\section{(Received 12 April 1984 - Accepted 2 August 1984)}

1. Studies of iron utilization and haem synthesis were carried out with hepatic mitochondria obtained from copper-deficient and pair-fed control rats.

2. Ferric chloride can be used as Fe substrate for mitochondrial haem synthesis in the presence of succinate. Utilization is further enhanced by the addition of FMN.

3. Ferritin does not support haem synthesis in the presence of succinate alone, but does support haem synthesis when FMN is added.

4. Mitochondrial haem synthesis is impaired in $\mathrm{Cu}$ deficiency when either $\mathrm{FeCl}_{3}$ or homologous ferritin is used as Fe substrate.

5. The results of the present study suggest that impaired haem synthesis in Cu deficiency occurs at a step following the chemical reduction of Fe substrate.

Copper deficiency results in impaired utilization of iron for haemoglobin production, an abnormality which is reflected in the development of microcytic hypochromic anaemia (Lee et al. 1976). This defect has been ascribed to a block of Fe movement into the transferrin $\mathrm{Fe}$ pool resulting from a reduction of the $\mathrm{Cu}$-dependent ferroxidase, caeruloplasmin ( $E C$ 1.16.3.1)(Roeser et al. 1970). This mechanism, however, does not adequately explain either the observations of $\mathrm{Fe}$ accumulation within $\mathrm{Cu}$-deficient erythroblasts (Goodman \& Dallman, 1969) or the previous demonstrations of impaired Fe uptake and reduced haem synthesis by $\mathrm{Cu}$-deficient reticulocytes (Williams et al. 1976).

Ferritin has been shown to be utilized by isolated mitochondria for haem synthesis when in the presence of FMN (Ulvik \& Romslo, 1979). It has been suggested that ferritin may represent the physiological Fe substrate for mitochondrial Fe utilization. The purpose of the present study was to compare haem synthesis by $\mathrm{Cu}$-deficient and by control hepatic mitochondria using either ferric chloride or ferritin as Fe substrate.

\section{MATERIALS AND METHODS}

Animals and diet

Male Sprague-Dawley rats were weaned at $21 \mathrm{~d}$ of age and housed in individual hanging stainless-steel cages. The animals were fed on a milk-based Cu-deficient diet which has been described previously (Williams et al. 1983). Cu-replete control animals were fed on a similar diet supplemented with $\mathrm{Cu}(1 \mathrm{mg} / \mathrm{d})$ by the matched-pair technique. All animals received Fe supplementation in the form of Fe dextran (Merrell-National, Cincinnati, Ohio), $10 \mathrm{mg}$ elemental $\mathrm{Fe}$, administered intramuscularly during the first week of the study. Animals were weighed weekly during the course of the study. After 6 weeks the rats were killed by carbon dioxide narcosis and exsanguination from the inferior vena cava. 


\section{Mitochondria}

Livers were harvested and perfused with ice-cold $0 \cdot 15 \mathrm{M}$-saline until clear of visible blood. The livers were blotted dry and minced in 10 vol. $0.25 \mathrm{M}$-sucrose, buffered to $\mathrm{pH} 7.4$ with 0.01 M-HEPES. Further homogenization in an ice-jacketed vessel was accomplished with the use of a Polytron tissue homogenizer (Brinkmann Instruments, Westbury, NY) for $15 \mathrm{~s}$ at a power setting of 5. Mitochondria were separated from other cellular constituents by density centrifugation in $0.25 \mathrm{M}$-sucrose using the method of Romslo \& Flatmark (1973). Functional integrity of the mitochondria was assessed by the measurement of oxygen consumption using succinate as substrate. Mitochondria were not used for further experiments if respiratory control, measured as the ratio of $\mathrm{O}_{2}$ consumption with and without ADP, was less than 3.0.

\section{Haem synthesis}

Haem synthesis by isolated mitochondria was carried out in Thunberg vessels which were prepared to contain mesoporphyrin (0.04 mm) (Porphyrin Products, Logan, Utah), potassium succinate $(8 \mathrm{~mm})$, sodium pyrophosphate $(0.01 \mathrm{~mm})$, HEPES buffer $(10 \mathrm{~mm})$,

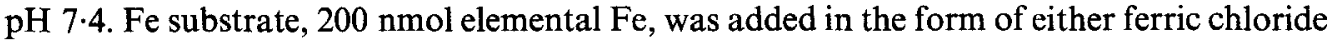
or ferritin. FMN (Sigma Chemical Co., St Louis, Missouri) was added in varying concentrations. Mitochondria $(0.5 \mathrm{ml}, 15 \mathrm{mg}$ protein $/ \mathrm{ml})$ were added to the side-arm. The total reaction volume was $3.0 \mathrm{ml}$. The vessels were evacuated and flushed with nitrogen three times, sealed under slight negative pressure and incubated for $10 \mathrm{~min}$ at $37^{\circ}$ in an oscillating water-bath. The reaction was then started by tipping in the mitochondria. The reaction mixture was incubated for $30 \mathrm{~min}$ at $37^{\circ}$ in the dark. The reaction was stopped by the introduction of $0.3 \mathrm{ml} 0.4 \mathrm{M}$-iodoacetamide into the side-arm. Total mesohaem was then measured by the method of Porra \& Jones (1963). Values were corrected using a nonenzymic blank in which quantities of synthesized haem were negligible. Haem synthesis was expressed as nmol haem synthesized/mg mitochondrial protein per $\mathrm{h}$. In some experiments, varying concentrations of FMN were added to the reaction mixture.

\section{Fe substrates}

Ferric chloride $(80 \mu \mathrm{M})$ was freshly prepared from anhydrous $\mathrm{FeCl}_{3}$ in $\mathrm{HEPES}$ buffer $(2 \cdot 0 \mathrm{~mm}), \mathrm{pH} 7 \cdot 4$, and added immediately to the reaction vessel. Horse spleen ferritin was purchased as cadmium-free recrystallized ferritin dissolved in $0 \cdot 15 \mathrm{M}-\mathrm{NaCl}$ (Sigma Chemical Co.) and diluted to working solution in HEPES buffer $(0.01 \mathrm{M}), \mathrm{pH} \mathrm{7.4}$. Rat ferritin was prepared from livers of rats treated chronically with intramuscular Fe dextran. Livers were homogenized and centrifuged at $5000 \mathrm{~g}$. The Fe-rich supernatant fraction was dialyzed against HEPES buffer $(0.01 \mathrm{M}), \mathrm{pH} 7 \cdot 4$, and subjected to chromatography with Sephacryl 200 , using a $9 \mathrm{~mm} \times 30 \mathrm{~mm}$ column with $15.6 \mathrm{ml}$ bed volume. The Fe-rich excluded volume was collected and concentrated by ultrafiltration. This material was compared against human and equine ferritin using Ouchterlony immunodiffusion.

\section{Analytical methods}

Haematological determinations were carried out by standard methods (Williams et al. 1983). $\mathrm{Fe}$ and $\mathrm{Cu}$ measurements were performed by atomic absorption spectroscopy following wet acid-digestion (Williams et al. 1976). Protein was measured by the method of Lowry et al. (1951). Caeruloplasmin was determined by the method of Ravin (1961). Cytochrome $c$ oxidase $(E C$ 1.9.3.1) was determined by the method of Wharton \& Tzagaloff (1967). Determinations of means and standard deviations were performed with a pre-programmed hand calculator (Texas Instruments, Dallas, Texas) and statistical significance was determined by the two-tailed Student's $t$ test. 
Table 1. Haematologic values and metal determinations in copper-deficient and pair-fed control rats

(Mean values with their standard errors for twelve animals per group)

\begin{tabular}{|c|c|c|c|c|c|}
\hline \multirow[b]{3}{*}{ Determination } & \multicolumn{4}{|c|}{$\mathrm{Cu}$ status } & \multirow{3}{*}{$\begin{array}{c}\text { Statistical } \\
\text { significance } \\
\text { of } \\
\text { difference } \\
P<\end{array}$} \\
\hline & \multicolumn{2}{|c|}{ Deficient } & \multicolumn{2}{|c|}{ Replete } & \\
\hline & Mean & $\mathrm{SE}$ & Mean & $\mathrm{SE}$ & \\
\hline Body-wt (g) & 121 & $6 \cdot 1$ & 161 & $6 \cdot 8$ & 0.001 \\
\hline Haemoglobin $(\mathrm{g} / \mathrm{l})$ & 101 & 6.9 & 171 & 1.8 & 0.001 \\
\hline Serum caeruloplasmin $(E C$ 1.16.3.1)* & 0.012 & 0.003 & 0.592 & 0.040 & 0.001 \\
\hline Serum $\mathrm{Cu}(\mu \mathrm{g} / \mathrm{l})$ & 120 & $19 \cdot 92$ & 1380 & 77.94 & 0.001 \\
\hline Serum Fe $(\mu \mathrm{mol} / \mathrm{l})$ & $9 \cdot 5$ & 0.98 & $33 \cdot 0$ & 1.91 & 0.001 \\
\hline Hepatic $\mathrm{Cu}(\mu \mathrm{g} / \mathrm{g}$ fresh wt) & 0.7 & 0.04 & $17 \cdot 3$ & $1 \cdot 24$ & 0.001 \\
\hline Hepatic $\mathrm{Fe}(\mu \mathrm{g} / \mathrm{g}$ fresh wt) & 491 & $15 \cdot 4$ & 293 & 17.6 & 0.001 \\
\hline Mitochondrial $\mathrm{Cu}(\mu \mathrm{g} / \mathrm{mg}$ protein) & 0.01 & 0.006 & $0 \cdot 10$ & 0.035 & 0.05 \\
\hline Mitochondrial $\mathrm{Fe}(\mu \mathrm{g} / \mathrm{mg}$ protein $)$ & $2 \cdot 9$ & $0 \cdot 17$ & $1 \cdot 6$ & $0 \cdot 11$ & 0.001 \\
\hline $\begin{array}{l}\text { Mitochondrial cytochrome } c \text { oxidase } \\
(E C \text { 1.9.3.1 } \dagger\end{array}$ & 0.096 & 0.0078 & 0.356 & 0.0231 & 0.001 \\
\hline Mitochondrial oxygen consumption $\ddagger$ & $0 \cdot 128$ & 0.0196 & $0 \cdot 248$ & 0.0670 & 0.05 \\
\hline
\end{tabular}

* Change in absorbance at $530 \mathrm{~nm} / 0 \cdot 1 \mathrm{ml}$ serum.

$\dagger$ nmol cytochrome $c$ oxidized/mg protein per min.

$\ddagger \mu \mathrm{l} / \mathrm{mg}$ protein per min.

\section{RESULTS \\ Production of $\mathrm{Cu}$ deficiency}

Haematological values and metal determinations for $\mathrm{Cu}$-deficient and pair-fed control rats are shown in Table 1. Cu-deficient and control animals grew at comparable rates throughout the first 5 weeks of the experiment. Subsequently, the $\mathrm{Cu}$-deficient animals lost an average of $7.4 \mathrm{~g}$ during the next weekly interval while control animals continued to grow. After 6 weeks, the $\mathrm{Cu}$-deficient rats were significantly smaller (Table 1). No intercurrent disease could be identified. Similar growth curves had been noted in other studies (data not shown). $\mathrm{Cu}$-deficient animals were anaemic. The $\mathrm{Cu}$ content of serum, whole liver and hepatic mitochondria was significantly decreased in $\mathrm{Cu}$-deficient animals as were levels of the cuproenzymes, caeruloplasmin and mitochondrial cytochrome $c$ oxidase. Oxygen consumption was reduced in $\mathrm{Cu}$-deficient mitochondria. Fe content of the liver was significantly increased in $\mathrm{Cu}$-deficient animals $(P<0.001)$ while serum $\mathrm{Fe}$ was significantly reduced $(P<0 \cdot 001)$.

\section{Rat liver ferritin}

The Fe-rich supernatant fraction obtained by centrifugation of liver homogenates was rendered homogenous by gel-sieving with Sepharose $4 \mathrm{~B}$ and was electrophoretically identical to rat ferritin prepared by the method of Drysdale \& Munro (1965). In addition, the material was identified as ferritin by Ouchterlony immunodiffusion.

\section{Haem synthesis by normal mitochondria}

When $\mathrm{FeCl}_{3}$ was used as $\mathrm{Fe}$ substrate, normal mitochondria synthesized $0.15 \mathrm{nmol}$ haem $/ \mathrm{mg}$ mitochondrial protein per $\mathrm{h}$ as measured by the mesohaem chromogen method. The rate of synthesis was linear over the interval of incubation. This synthesis was enhanced to $3.4 \mathrm{nmol} / \mathrm{mg}$ mitochondrial protein per $\mathrm{h}$ when succinate $(8 \mathrm{~mm})$ was added. Again, the rate of haem synthesis was linear over the interval of incubation. In all subsequent studies, succinate was added to the reaction mixture. 


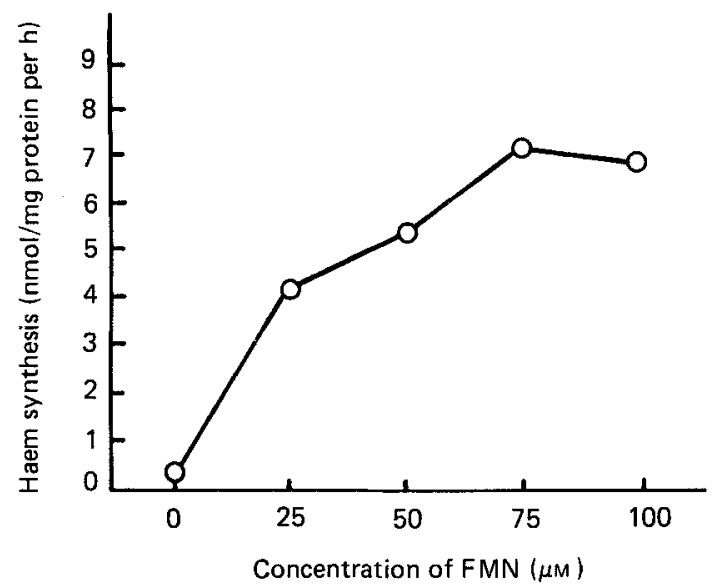

Fig. 1. Effect of FMN on haem synthesis by copper-replete hepatic mitochondria. Mitochondria were incubated with ferric chloride ( $200 \mathrm{nmol}$ iron) and varying concentrations of FMN in the usual reaction mixture. Haem synthesis increased with increasing amounts of FMN, with little increase beyond a concentration of $75 \mu \mathrm{M}$.

Table 2. Effect of FMN on haem synthesis in control mitochondria with various iron substrates

(Mean values with their standard errors)

\begin{tabular}{ccccc}
\hline \hline & & & \multicolumn{2}{c}{$\begin{array}{c}\text { Mitochondrial haem synthesis } \\
\text { (nmol/mg protein per h) }\end{array}$} \\
\cline { 4 - 5 } Fe substrate & $n$ & $\begin{array}{c}\text { FMN } \\
(75 \mu \mathrm{M})\end{array}$ & Mean & SE \\
\hline Ferric chloride & 6 & 0 & $5 \cdot 2$ & 0.41 \\
(200 nmol Fe) & & + & $7 \cdot 4$ & $0 \cdot 16$ \\
Horse spleen ferritin & 7 & 0 & 0.1 & 0.08 \\
(200 nmol Fe) & & + & $5 \cdot 4$ & 0.68 \\
Rat liver ferritin & 4 & 0 & 0.6 & 0.20 \\
(200 nmol Fe) & & + & 6.1 & 0.75 \\
\hline \hline
\end{tabular}

0, Absent; +, present.

When ferritin was used as Fe substrate with normal mitochondria there was virtually no haem synthesis in the absence of FMN, but there was increasing haem synthesis with increasing concentrations of FMN until a plateau was reached at $75 \mu \mathrm{M}$ (Fig. 1). In subsequent experiments, haem synthesis from ferritin was measured in the presence of FMN $(75 \mu \mathrm{M})$. Utilization of $\mathrm{Fe}$ from either horse spleen ferritin or rat liver ferritin was dependent on FMN (Table 2). When $\mathrm{FeCl}_{3}$ was used as Fe substrate, mitochondrial haem synthesis occurred in the absence of FMN but was further enhanced in the presence of FMN (Table 2).

\section{Haem synthesis by Cu-deficient mitochondria}

Haem synthesis by $\mathrm{Cu}$-deficient hepatic mitochondria was impaired when compared with mitochondria obtained from matched pair-fed controls either when $\mathrm{Fe}$ was provided as $\mathrm{Fe}^{3+}$ or when it was provided in homologous hepatic ferritin (Table 3 ). 
Table 3. Comparison of haem synthesis by copper-deficient and control hepatic mitochondria using various iron substrates

(Mean values with their standard errors for twelve animals per group)

\begin{tabular}{|c|c|c|c|c|c|}
\hline \multirow[b]{3}{*}{ Fe substrate } & \multicolumn{4}{|c|}{$\begin{array}{l}\text { Mitochondrial haem synthesis } \\
\text { (nmol/mg mitochondrial protein per } h \text { ) }\end{array}$} & \multirow{3}{*}{$\begin{array}{c}\text { Statistical } \\
\text { significance } \\
\text { of } \\
\text { difference } \\
P<\end{array}$} \\
\hline & \multicolumn{2}{|c|}{ Copper deficient } & \multicolumn{2}{|c|}{ Control } & \\
\hline & Mean & SE & Mean & SE & \\
\hline Ferric chloride $(200 \mathrm{nmol} \mathrm{Fe})$ & $3 \cdot 3$ & 0.52 & 5.0 & 0.26 & 0.01 \\
\hline Rat liver ferritin $(200 \mathrm{nmol} \mathrm{Fe})$ & $6 \cdot 2$ & $1 \cdot 10$ & $10 \cdot 3$ & 0.78 & 0.01 \\
\hline
\end{tabular}

\section{DISCUSSION}

Hepatic Fe accumulation is a consistent feature of $\mathrm{Cu}$ deficiency which increases during the course of the deficiency even as anaemia progresses (Williams et al. 1983). It has been presumed, because the liver is an important Fe storage site, that this hepatic Fe accumulation reflects impaired transport of $\mathrm{Fe}$ into the plasma compartment for subsequent utilization for haemoglobin synthesis (Evans \& Abraham, 1973). Further, this defect has been assumed to be due to deficiency of the $\mathrm{Cu}$-containing plasma ferroxidase, caeruloplasmin (Roeser et al. 1970).

Caeruloplasmin administration has been shown to increase hepatic Fe release in vitro (Osaki \& Johnson, 1969) and to increase the plasma Fe concentration in vivo (Roeser et al. 1970), but recent studies have suggested that hepatic Fe release at physiological $\mathrm{O}_{2}$ tension may not require caeruloplasmin (Baker et al. 1980). Further, plasma ferroxidase activities have been identified which are not $\mathrm{Cu}$ dependent and which presumably would be active in $\mathrm{Cu}$ deficiency (Prohaska, 1983).

Besides its important role in $\mathrm{Fe}$ storage, the liver also plays a major role in $\mathrm{Fe}$ utilization. Although there are important differences of $\mathrm{Fe}$ metabolism in hepatocytes and erythroid precursors, both cell lines are rich in transferrin receptors (Seligman, 1983), and both cell lines synthesize large amounts of Fe-containing haem proteins and contain an active ferrochelatase ( $E C$ 4.99.1.1) system.

The major product of hepatic ferrochelatase activity is the cytochrome $\mathrm{P} 450$ system which approaches erythrocytic haemoglobin synthesis in terms of quantity (Ibrahim et al. 1983). Thus, if hepatic haem synthesis were impaired, $\mathrm{Fe}$ accumulation might be expected to occur as a consequence of impaired $\mathrm{Fe}$ utilization. This alternative explanation would not require a direct enzymic role for caeruloplasmin. Moreover, it might explain the accumulation of ferritin in $\mathrm{Cu}$ deficiency since recent studies have provided evidence that ferritin may serve as a precursor in normal haem synthesis (Nunez et al. 1978). Further, Ulvik \& Romslo (1979) have suggested that ferritin may serve as an Fe donor in mitochondrial haem synthesis.

These studies confirm the observation that mitochondrial haem synthesis may be supported by either inorganic Fe or by ferritin-Fe (Ulvik \& Romslo, 1979). However, there are differences in mitochondrial utilization of $\mathrm{Fe}$ from these two sources. $\mathrm{Fe}^{3+}$ utilization is little enhanced by the addition of flavin derivatives while ferritin-Fe utilization is dependent on FMN. This requirement for FMN has been observed when $\mathrm{Fe}^{3+}$ is used as substrate for erythroid membrane ferrochelatase activity (Barnes \& Jones, 1973) or when ferritin is used as substrate for mitochondrial haem synthesis (Ulvik \& Romslo, 1979). It has been suggested that flavins may penetrate the ferritin shell to provide a means of rapid $\mathrm{Fe}$ reduction (Jones et al. 1978) and that NADH dehydrogenase (NADH-FMN 
oxidoreductase; $E C$ 1.6.99.3) may serve as a controlling enzyme for Fe release from ferritin (Sirivech et al. 1977). Although reported levels for FMN in rat liver are somewhat lower (15-18 $\mu \mathrm{M})$ than optimal concentrations observed in the present study, availability of FMN in whole tissues may be comparable since tissue FMN is apparently highly localized and bound to specific proteins (Jones et al. 1978). However, it does appear that Fe reduction must occur for maximal mitochondrial utilization whether ferritin or inorganic Fe serves as substrate.

A model has been proposed in which $\mathrm{Fe}$ and porphyrin are transported across the mitochondrion in a linked process. Fe uptake appears to require at least two steps, one of which is energy dependent and the other energy independent. Fe is then reduced and incorporated into haem which is transported out of the mitochondria by an undefined process (Romslo \& Husby, 1980).

In $\mathrm{Cu}$ deficiency, $\mathrm{Fe}$ utilization by hepatic mitochondria is similar to that observed in normal mitochondria. In both instances, however, there is significant reduction of haem synthesis when compared with controls. Thus, there appears to be a defect of Fe utilization by $\mathrm{Cu}$-deficient mitochondria. The nature of this defect is not clear. Although the $\mathrm{Cu}$ protein, cytochrome $c$ oxidase, is essential for intact electron transport, the reduction of ferritin-Fe by NADH dehydrogenase is presumably not dependent on this enzyme. Thus, the possibilities that $\mathrm{Cu}$ deficiency might impair mitochondrial binding of ferritin or result in abnormalities of Fe transport, NADH dehydrogenase activity or even ferrochelatase activity must also be considered. Studies are presently underway to define these considerations more clearly.

This work was supported in part by a grant, AM 23004, from the Public Health Service, Bethesda, Maryland, USA.

\section{REFEREN CES}

Baker, E., Morton, A. G. \& Tavill, A. S. (1980). British Journal of Haematology 45, 607-620.

Barnes, R. \& Jones, O. T. G. (1973). Biochimica et Biophysica Acta 304, 304-308.

Drysdale, J. W. \& Munro, H. N. (1965). Biochemical Journal 95, 851-858.

Evans, J. L. \& Abraham, P. A. (1973). Journal of Nutrition 103, 196-201.

Goodman, J. R. \& Dallman, P. R. (1969). Blood 34, 747-753.

Ibrahim, N. G., Friedland, M. L. \& Levere, R. D. (1983). Progress in Hematology 13, 75-130.

Jones, T., Spencer, R. \& Walsh, C. (1978). Biochemistry 17, 4011-4017.

Lee, G. R., Williams, D. M. \& Cartwright, G. E. (1976). In Trace Elements in Human Health and Disease, vol. 1, Zinc and Copper, pp. 373-393 [A. S. Prasad and D. Oberleas, editors]. New York: Academic Press.

Lowry, O. H., Rosebrough, N. J., Farr, A. L. \& Randall, R. J. (1951). Journal of Biological Chemistry 193, 265-275.

Nunez, M. T., Glass, J. \& Robinson, S. H. (1978). Biochimica et Biophysica Acta 509, 170-180.

Osaki, S. \& Johnson, D. A. (1969). Journal of Biological Chemistry 244, 5757-5765.

Porra, R. J. \& Jones, O. T. G. (1963). Biochernical Journal 87, 181-185.

Prohaska, J. R. (1983). Journal of Nutrition 113, 2048-2058.

Ravin, H. A. (1961). Journal of Laboratory and Clinical Medicine 58, 161-168.

Roeser, H. P., Lee, G. R., Nacht, S. \& Cartwright, G. E. (1970). Journal of Clinical Investigation 49, $2408-2417$.

Romslo, I. \& Flatmark, T. (1973). Biochimica et Biophysica Acta 305, 29-40.

Romslo, I. \& Husby, P. (1980). International Journal of Biochemistry 12, 709-712.

Seligman, P. A. (1983). Progress in Hematology 13, $131-417$.

Sirivech, S., Driskell, J. \& Frieden, E. (1977). Journal of Nutrition 107, 739-745.

Ulvik, R. \& Romslo, I. (1979). Biochimica et Biophysica Acta 588, 256-271.

Wharton, D. C. \& Tzagaloff, A. (1967). In Methods in Enzymology, vol. 10, pp. 245-250 [R. W. Estabrook and

M. E. Pullman, editors]. New York: Academic Press.

Williams, D. M., Kennedy, F. S. \& Green, B. G. (1983). British Journal of Nutrition 50, 653-660.

Williams, D. M., Loukopoulos, D., Lee, G. R. \& Cartwright, G. E. (1976). Blood 48, $77 \sim 85$. 